\title{
臨床応用を目指した薬学の基礎研究
}

\author{
内藤幹彦, ${ }^{*}, a$ 益見厚子 $b$
}

\section{Pharmaceutical Basic Researches Aiming at Clinical Applications}

\author{
Mikihiko Naito*,a and Atsuko Masumi ${ }^{b}$ \\ ${ }^{a}$ National Institute of Health Sciences; 1-18-1 Kamiyoga, Setagaya-ku, Tokyo 158-8501, \\ Japan: and ${ }^{b}$ Natinal Institute of Infectious Diseases; 4-7-1 Gakuen, \\ Musashimurayama, Tokyo 208-0011, Japan.
}

薬学研究の主要な目的の 1 つは, その研究成果を 病気に苦しむ患者さんの治療に役立てることにあ る. 基礎研究を単なる基礎研究で終わらせないよう にするためには，基礎研究の段階から臨床応用への 明確な目的意識を持って研究に携わることが重要で あると思われる. 日本薬学会第 133 回年会シンポジ ウムS30-106では，「臨床応用を目指した薬学の基 礎研究」をメインテーマとして, 臨床応用に成功又 は近いところまで進んだ研究の実例を 4 つとり上 げ，基礎研究の成果を臨床応用に結びつけるために 基礎研究者はどのような意識で研究に取り組む必要 があるかについて議論した。この誌上シンポジウム では, シンポジウムでの発表内容を基に 3 人のシン ポジストに総説を御執筆頂いた.

「経皮ワクチン製剤（貼るワクチン）の基礎から 臨床」（岡田直貴氏の稿）では，感染症対策におけ るワクチンの有用性，ワクチンの標的組織としての 皮膚の有用性，経皮的ワクチンデリバリー技術の歴 史，さらに岡田氏らの研究室で開発が進んでいる皮 膚内溶解型マイクロニードルパッチを用いた経皮ワ クチン製剂について述べられている。インフルエン ザパンデミックなど世界的な規模での感染症流行の 危険にさらされている現代社会において，従来型の 注射製剂ワクチンと比べ安全性・簡便性・経済性に 優れた「貼るワクチン」の実用化は，社会的にも大 きな期待と関心を集めている.

$a^{a}$ 国立医薬品食品衛生研究所（T158-8501 東京都世田 谷区上用賀 1-18-1)， $b$ 国立感染症研究所（干208-0011 東京都武蔵村山市学園 4-7-1)

*e-mail: miki-naito@nihs.go.jp

日本薬学会第 133 年会シンポジウム S30-106 序文
「バイオマーカー探索研究とその臨床応用に向け て」（斎藤嘉朗氏の稿）では，医薬品開発の効率化 と医薬品の安全使用のために, 適切なバイオマー カーが有用であることが述べられている，遺伝子多 型に代表されるゲノムバイオマーカーは，抗がん剂 の副作用や重症薬疹の発現を予測する有用な指標と なっており, 斎藤氏らの研究成果を基にした注意喚 起が，イリノテカン（抗がん剂）やアロプリノール （痛風治療薬）などの医薬品添付文書に記載されて いる。またゲノム，エピゲノム，トランスクリプ トーム，プロテオーム，メタボロームの多層的オミ ックス解析を基にした疾患関連バイオマーカー探索 研究が現在進行中であり, 斎藤氏らの研究室で行つ ているメタボローム解析の取り組みと研究成果の一 部をご紹介頂いた。

「ヒ卜人工多能性幹細胞由来移植細胞の製造管理 のための in vitro 造腫瘍性評価系の開発」（佐藤陽 治氏の稿）では，近年ますます注目を集めている再 生医療の臨床応用にむけた細胞製品の評価系につい て述べられている。 ヒト多能性幹細胞（ES 細胞, iPS 細胞）には造腫瘍性があるため，分化誘導した 細胞製品への未分化細胞の混入による腫瘍形成のリ スクが指摘されている，佐藤氏らの研究室では，未 分化細胞特異的に発現する LIN 28 を指標に, 混入 した未分化 iPS 細胞を高感度に検出する評価系を 開発した。この評価系は，世界初の iPS 細胞由来 網膜色素上皮細胞を用いた臨床研究での品質管理試 験法として用いられることになっている.

ここに挙げた 3 編の総説は, 研究内容における共 通性はあまりないかもしれないが，それぞれの研究 成果を臨床応用に結びつけるために意欲的に研究を 
展開しているという共通点がみられる。これらの総 向性を考える上での一助となれば幸いである. 説が, 薬学の若い研究者にとって, 将来の研究の方 